\title{
The role of estrogen receptor beta in breast cancer
}

\author{
Yujing Zhou and Xingdang Liu* (D)
}

\begin{abstract}
Breast cancer, a malignant tumor originating from mammary epithelial tissue, is the most common cancer among women worldwide. Challenges facing the diagnosis and treatment of breast cancer necessitate the search for new mechanisms and drugs to improve outcomes. Estrogen receptor (ER) is considered to be important for determining the diagnosis and treatment strategy. The discovery of the second estrogen receptor, ER $\beta$, provides an opportunity to understand estrogen action. The emergence of ER $\beta$ can be traced back to 1996. Over the past 20 years, an increasing body of evidence has implicated the vital effect of ER $\beta$ in breast cancer. Although there is controversy among scholars, $E R \beta$ is generally thought to have antiproliferative effects in disease progression. This review summarizes available evidence regarding the involvement of ERß in the clinical treatment and prognosis of breast cancer and describes signaling pathways associated with ERß. We hope to highlight the potential of ERß as a therapeutic target.
\end{abstract}

Keywords: Estrogen receptor $\beta$, Breast cancer, Biomarker, Prognosis, Mechanism

\section{Background}

Breast cancer, a malignant tumor originating from mammary epithelial tissue, is the most common cancer among women worldwide [1]. With the discovery of multiple receptors, the treatment of breast cancer has been greatly advanced. Among them, estrogen receptor (ER) is considered to be important for determining the diagnosis and treatment strategy. In the 1960s, ER $\alpha$, the first estrogen receptor, was described [2]. After a long period of research, the function of ER $\alpha$ is now well characterized [3], and ER $\alpha$ is widely used for determining medication and imaging strategies $[4,5]$.

The emergence of the second ER, ER $\beta$, can be traced back to 1996 [6]. After its discovery, much effort has been devoted to the question of the unique functions of ER $\beta$ and its potential as a novel target for pharmacological intervention [7, 8]. At present, the widespread expression of ER $\beta$ is detected not only in luminal and myoepithelial cells in the normal breast but also in

\footnotetext{
* Correspondence: xingdliu@fudan.edu.cn

Department of Nuclear Medicine, Huashan Hospital, Fudan University, No.12 Urumchi Middle Road, Jing'an District, Shanghai 200040, China
}

subcutaneous adipose tissue [9] and prostate, testis, uterus, ovary, and brain tissues [10]. Alternations in estrogenic signaling pathways, as well as ER $\beta$ expression, have been discussed in the context of physiological and pathological processes, such as maintenance of the bone marrow microenvironment [11], neuronal-mediated contractions of the gastrointestinal tract [12], recovery of reproductive system injury [13], anxiolytic effects [14], and diseases such as Parkinson's disease [15], endometriosis [16], myocardial infarction [17] and type 2 diabetes [18]. Moreover, ER $\beta$ has been shown to participate in the pathological process of various cancers, including uterine leiomyomas [19], colorectal cancer [20], desmoid tumors [21], prostate cancer [22] and duct carcinoma [23].

The association between the activation of ER $\beta$ and early transcription and mRNA splicing in breast cancer $[24,25]$ is well studied. The mechanism of preferential ER $\beta$ ligands has also been discussed [26]. However, the significance of ER $\beta$ expression and its potential role in normal mammary development and breast cancer remain controversial. In this review, the current state of research addressing the roles of ER $\beta$ in breast cancer is 
summarized, with a particular focus on the past ten years.

\section{ER $\beta$}

Human ER $\beta$ is a member of the nuclear transcription factor superfamily, is encoded by the ESR2 gene (14q23.2), and is composed of 530 amino acids [27]. The DNA binding domain and ligand binding domain of the ER $\beta$ protein are 96 and $60 \%$ homologous with those of $E R \alpha$, indicating that they may have similar but not identical functions [28]. ER $\beta$ is abundant in the majority of normal breast epithelial cells and is thought to be present in $20-30 \%$ of breast cancers [29]. However, as research progresses, the positive rate of ER $\beta$ in breast cancer has been reported to be over $60 \%$ [30, 31]. The five full-length ER $\beta$ variants, which result from alternative splicing of the last coding exon, deletion of coding exons, or alternative usage of untranslated exons and are named ER $\beta 1-5$, can be detected in various normal tissues, breast cancer tissues and breast cancer cell lines [32, 33]. Additionally, ER $\beta \mathrm{cx}$, the carboxy terminal splicing variant of ER $\beta$, plays a role that ER $\beta$ cannot [34]. Different isoforms, as well as polymorphisms, may have different associations with tumor characteristics and prognosis [35]. For instance, a study including 150 Iranian women with breast cancer and 147 healthy individuals found that the ER $\beta$ polymorphism in exon 7 codon 392 (C1176G) was associated with the occurrence of lymph node metastasis [36]. Genotype frequencies of SNPs, such as rs3020449, rs3020450, rs2987983, rs1271572 and rs1887994 SNP rs4986938, have been discussed [37, 38], and some were found to be associated with increased or decreased risk for breast cancer $[38,39]$.

\section{Prognostic value of ER $\beta$ in breast cancer}

The research regarding the detection of ER $\beta$-like protein established a platform for investigating the relationships between protein expression and patient outcome. The review in 2012 showed that most but not all of the studies indicated an association between higher levels of ER $\beta$-like protein and better clinical outcome, often in patients who were treated with tamoxifen (TAM) [40]. Notably, more than one study found that the expression of ER $\beta$ protein had no significant correlation with clinical variables, including tumor size, age, or axillary nodal status [41-43]. Interestingly, a significant decrease in ER $\beta$ gene expression in tissues was observed in a cohort of 120 patients with phase II to phase IIIA breast cancer after chemotherapy [44]. However, in another study including 78 women who were postmenopausal with primary stage II to III invasive breast cancer, ER $\beta$ did not change when comparing samples from before and after endocrine treatment [45]. Since the role of ER $\beta$ in breast cancer remains unclear, the latest studies have made efforts to explore the relationship between ER $\beta$ and clinical outcome in many aspects, including the predictive value of ER $\beta$ expression [46], the ER $\beta$ to ER $\alpha$ ratio [45] and the DNA promoter hypermethylation of ER $\beta$ [47], especially in patients who have undergone endocrine therapy [48, 49] and chemotherapy [44, 50]. In general, numerous studies have verified that ER $\beta$ is an independent prognostic and/or predictive factor in breast cancer, although the conclusion is still controversial. Studies reporting a correlation of ER $\beta$ with clinical outcome for the last 10 years are shown in Table 1.

Multiple studies have now been published in which ER $\beta$ shows its anticancer effect and helps predict treatment responsiveness, irrespective of the ER $\alpha$ status. In a prospective cohort of 1026 patients diagnosed with primary invasive breast cancer, ER $\beta 1$ positivity, defined as $>75 \%$ staining, was associated with a lower risk of breast cancer compared with ER $\beta 1<75 \%$ tumors. Among 232 patients who underwent chemotherapy, ER $\beta 1$ staining > $75 \%$ in tumors was associated with a lower risk of breast cancer events. High ER $\beta 1$ expression was a favorable prognostic marker in breast cancer, especially in patients receiving chemotherapy [30]. Similarly, another study indicated that positive nuclear ER $\beta 1$ expression was correlated with longer 15-year survival in patients treated with TAM [50]. Using mass spectrometry, studies identified serine 105 (S105) in the N-terminus of ER $\beta$, and S105-ER $\beta$ immunoreactivity was detected with a higher prevalence and intensity than that of ER $\beta 1$ [59]. Nuclear S105-ER $\beta$ was associated with better survival, even in tamoxifen-resistant cases [58].

However, there are limited studies that reported opposite results, in which elevated ER $\beta$ and cytoplasmic ER $\beta 2$ expression predict poor prognosis [50, 57]. For example, Guo et al. showed that compared to patients with low ER $\beta$ expression, patients with high ER $\beta$ expression in breast cancer tissue displayed a significantly lower median tumor-free survival time [48]. Another study of 195 postmenopausal females with stage I or II ER $\alpha$ positive breast cancer who underwent endocrine therapy showed that ER $\beta$ overexpression results in reduced disease-free survival (DFS) and poor prognosis [49].

Triple-negative breast cancers (TNBCs) lack ER $\alpha$, progesterone receptor (PR), and human epidermal growth factor receptor-2 (HER2) amplification, and due to the poor response to chemotherapy, TNBC patients would benefit greatly if new targeted therapeutics were identified [52]. Scholars have made efforts to find the expression pattern of ER $\beta$ in TNBC and determine its significance in prognosis. Evidence has shown that the ER $\beta$ expression rate was significantly decreased in patients with TNBC compared with those with triple-positive breast cancer [54]. The conclusions are inconsistent. A study showed that no strong association was found between ER $\beta 1$ expression and DFS and overall survival (OS) in a TNBC 
Table 1 ER $\beta$ and clinical outcome

\begin{tabular}{|c|c|c|c|c|c|}
\hline$E R \beta$ isoform & ERß expression & ERa status & Number of patients & Clinical outcome & Year (Ref.) \\
\hline$E R \beta$ & $\uparrow$ & - & 1400 & reduced RFS & 2018 [51] \\
\hline$E R \beta$ & & & 32 & worse prognosis & 2017 [46] \\
\hline$E R \beta$ & $\uparrow$ & $+/-$ & 1026 & better prognosis & 2017 [30] \\
\hline$E R \beta$ & $\uparrow$ & & 120 & worse prognosis & 2017 [44] \\
\hline$E R \beta$ & & - & 17 & no association with PFS & 2016 [52] \\
\hline$E R \beta$ & $\uparrow$ & + & 195 & reduced DFS; reduced DFS after endocrine therapy & 2016 [49] \\
\hline Nuclear ERß1 & & - & 126 & no association with DFS and OS & 2015 [53] \\
\hline$E R \beta$ & $\uparrow$ & + & 127 & no association with PFS & 2015 [54] \\
\hline$E R \beta$ & $\uparrow$ & - & 107 & reduced DFS & 2015 [54] \\
\hline Nuclear ERß1 & $\uparrow$ & - & 19 & reduced OS & 2015 [55] \\
\hline ERß1 & & - & 571 & prolonged OS, DFS, and DMFS & $2015[56]$ \\
\hline$E R \beta$ & $\uparrow$ & $+/-$ & 583 & worse prognosis; worse endocrine therapy response & 2014 [48] \\
\hline$E R \beta$ & ERa/ERß: 1-1.5 & & 78 & better hormonal treatment response & 2013 [45] \\
\hline$E R \beta$ & $\downarrow$ & & 89 & reduced OS & 2012 [47] \\
\hline Nuclear ERß1 & $\uparrow$ & $+/-$ & 123 & better chemotherapy therapy and endocrine therapy response & $2011[50]$ \\
\hline Cytoplasmic ERß 2/Cx & & $+/-$ & 123 & poor chemotherapy response & $2011[50]$ \\
\hline$E R \beta$ & $\downarrow$ & & 41 & prolonged PFS; better aromatase inhibitor therapy response & $2010[57]$ \\
\hline Nuclear P-S105-ERß & $\uparrow$ & $+/-$ & 459 & better prognosis & $2010[58]$ \\
\hline
\end{tabular}

RFS Recurrence-free survival, PFS Progression-free survival, DFS Disease-free survival, OS Overall survival, DMFS Distant metastases-free survival.

cohort [53]. However, in a cohort of 571 TNBC patients, ER $\beta 1$ predicted better OS, DFS, and distant metastasisfree survival (DMFS) [56]. In contrast, ER $\beta 1$ was found to be associated with significantly worse 5-year OS in TNBC patients [55]. Moreover, a study indicated that patients with TNBC and positive ER $\beta$ expression exhibited poorer DFS [54] and decreased recurrence-free survival (RFS) regardless of chemotherapy use [51].

\section{Roles of ER $\beta$ in breast cancer therapy}

Questions regarding the relationship between the role of $E R \beta$ and the treatment of breast cancer have prompted studies about ER $\beta$ and drugs. TAM is a standard selective estrogen receptor modulator (SERM) that can be used as an adjuvant therapy for breast cancer recurrence in patients whose primary tumors are ER $\alpha$ positive. The role of ER $\beta$ in TAM therapy has been studied [60]. In TAM-treated cells, ER $\beta$ overexpression led to an increase in autophagy, which reduced cell viability [61]. ER $\beta$ also increased TAM-induced cell death and induced the expression of the proapoptotic gene BIK in cooperation with TAM [62]. TAM engaged mitochondrial ER $\beta$ as an antagonist, increasing reactive oxygen species (ROS) concentrations from the mitochondria that were required for cytotoxicity [63]. By recruiting ER $\beta$, cJun, cFos, binding protein (CBP), and RNA polymerase II to and dismissing NCoR from the nuclear respiratory factor 1 (NRF-1) promoter, TAM increased NRF-1 expression. Despite this, TAM-induced NRF-1 transcription was likely mediated by ER $\beta$ [64]. Additionally, ER $\beta$ enhanced the sensitivity of breast cancer cells to TAM [65-67]. ER $\beta$ re-expression was thought to sensitize MCF-7/TAM-R cells to the growth inhibitory and proapoptotic effects of TAM, thereby indicating that ER $\beta$ re-expression was directly linked to restoring TAM sensitivity [68].

Many drug treatments have been shown to be mediated by ER $\beta$ and its isoforms [69-71]. ER $\beta$ can enhance the antiproliferative effects of raloxifene $[72,73]$ and the sensitivity to anti-androgens in TNBC [74]. After treating MCF-7 cells with cisplatin, the overexpression of ER $\beta$ contributed to the lower rates of apoptosis, autophagy and ROS production, leading to increased cell survival. The opposite results were found by silencing ER $\beta$ in T47D cells [61].

\section{Mechanisms of ER $\beta$ suppressing breast cancer progression}

Over the years, researchers have discovered many mechanisms of ER $\beta$ in inhibiting tumor progression, especially in breast cancer. ER $\beta$ signaling is known to be complex and multifaceted and not just a component of a linear signaling pathway. Overall, the mechanisms associated with ER $\beta$ in vivo and in vitro models indicate that ER $\beta$ may act as a tumor suppressor.

\section{The interaction of $E R a$ and $E R \beta$ in breast cancer}

Some researchers believe that the changes in ER $\alpha$ and ER $\beta$ expression in the normal breast support a direct 
correlation between the nuclear expression of ERs and the proliferative nature of the breast [75]. The relative levels of ER $\beta$ and ER $\alpha$ in breast cancer are related to the activities of multiple signaling pathways responsible for cell proliferation and endocrine therapy response [45, 76]. A study shows that under the condition of coexpression of ER $\alpha$ and ER $\beta$, HER2 expression is frequently found to be negative, whereas the Ki-67 index is upregulated, indicating an association between this special combination of biomarkers and breast cancer aggressiveness [46]. Furthermore, elevated ER $\beta$ can affect ER $\alpha$ expression at the transcriptional level through downregulation of basal ER $\alpha$ promoter activity. The proximal GC-rich motifs at -223 and -214 are essential for ER $\beta$-induced $E R \alpha$ downregulation in breast cancer cells. This downregulation of ER $\alpha$ occurs through ER $\beta$-Sp1 proteinprotein interactions within the ER $\alpha$ promoter region and recruitment of a corepressor complex containing the nuclear receptor corepressor NCoR, hypoacetylation of histone $\mathrm{H} 4$ and displacement of RNA-polymerase II [77]. The use of an ER $\beta$-specific agonist significantly decreases the expression and functional activity of ER $\alpha$ in MCF-7 breast cancer cells, accompanied by decreased transcription of a downstream effector, breast cancerassociated gene 2 (BCA2) [78].

Additional evidence shows that tumors with a low $E R \alpha / E R \beta$ ratio have increased oxidative damage, antioxidant enzyme protein levels and uncoupling protein (UCP) and sirtuin 3 (SIRT3) protein levels. Glutathione peroxidase, complex V, complex III, complex II, complex IV, protein kinase B (AKT), stress-activated protein kinase (SAPK), and ER $\alpha$ are positively correlated with the $E R \alpha / E R \beta$ ratio, while carbonyl groups, catalase, CuZnsuperoxide dismutase, UCP5, SIRT3, and ER $\beta$ are negatively correlated with the $E R \alpha / E R \beta$ ratio [79]. It is reasonable to suggest that the imbalance of two estrogen receptors may lead to the occurrence of breast cancer .

\section{Phosphatidylinositol-3-kinase (PI3K)/AKT pathway}

The PI3K/AKT pathway is a common pathway in tumors and is negatively regulated by phosphatase and tensin homolog deleted on chromosome ten (PTEN). This pathway can regulate cellular proliferation, invasion, apoptosis, and hypoxia-related protein upregulation [80]. Indeed, the activation of the PI3K/AKT pathway acts as an important mechanism of ER $\beta$ downregulation in breast cancer and is thought to be associated with PTEN [56, 81]. The enhancement of PI3-K/Akt signaling and synergistic activation of coactivator cAMP response element-binding (CREB)-CBP induces ER $\beta$ ubiquitination and degradation. This process is potentiated by a negatively charged hinge region of ER $\beta$. Activated Akt triggers the recruitment of the E3 ubiquitin ligase $M D M 2$ to $E R \beta$, which is further stabilized by CBP, resulting in ER $\beta$ polyubiquitination [82]. By increasing PTEN levels and decreasing protooncogene HER2/HER3 signaling, Akt signaling is reduced. Expression of ER $\beta$ in ER $\alpha$-positive T47D and MCF-7 cells results in a decrease in Akt signaling and a decrease in the active form of an upstream regulator of Akt, the HER2/HER3 receptor dimer [65] (Fig. 1).

\section{Roles of ER $\beta$ in breast cancer cell migration and invasion}

It must be pointed out that ER $\beta$ plays an important role in the cell behavior and extracellular matrix (ECM) composition of breast cancer cells and may have an effect on important chemokine receptors [83, 84]. It is also involved in the beclin1-dependent autophagic cascade [85].

To understand the underlying mechanisms of ER $\beta$ in the migration of breast cancer, Piperigkou $\mathrm{Z}$ et al. knocked down the human ER $\beta$ gene to suppress $E R \beta$ expression in MDA-MB-231 breast cancer cells. The downregulation of ER $\beta$ decreases the expression of fibronectin and vimentin while increasing the expression of E-cadherin and cell junctions. In addition, ER $\beta$ plays a vital role in the gene expression of proteoglycans syndecans-2/-4 and serglycin, several matrix metalloproteinases, plasminogen activation system components and receptor tyrosine kinases. The downregulation of ER $\beta$ prevents breast cancer cell migration through tyrosine kinase receptor [epidermal growth factor receptor (EGFR)/insulin-like growth factor-I receptor (IGF-IR)] and Janus kinase/signal transducer and activator of transcription (JAK/STAT) signaling pathways [86].

However, ER $\beta 1$ is found to have an opposite regulatory effect on E-cadherin. Considering the positive correlation between the expression of ER $\beta 1$ and E-cadherin in breast cancer samples, Thomas and colleagues investigated the role of ER $\beta 1$ in epithelial-mesenchymal transition (EMT) and basal-like breast cancer cell invasion. In a subsequent work, they concluded that ER $\beta 1$ inhibits EMT and invasion in basal-like breast cancer cells when growing either in vitro or in vivo in zebrafish. The inhibition of EMT is related to the upregulation of miR-200a/ $b / 429$ by ER $\beta 1$ and the subsequent repression of zinc finger E-box-binding homeobox 1 (ZEB1) and smad interacting protein (SIP1), which contributes to the increased expression of E-cadherin. By stabilization of the ubiquitin ligase $\mathrm{c}-\mathrm{Cbl}$ complexes and subsequent ubiquitylation and degradation of the activated receptor, EGFR, a basal marker, is downregulated. This process is involved in ER $\beta 1$-mediated EMT inhibition and EGFR signal transduction, which eliminates the ability of ER $\beta 1$ to sustain the epithelial phenotype [87]. A similar function of ER $\beta 1$, in which it downregulates ZEB1 and thereby regulates the expression of E-cadherin, is also found in AR-positive TNBC cells. The activated AR in TNBC 


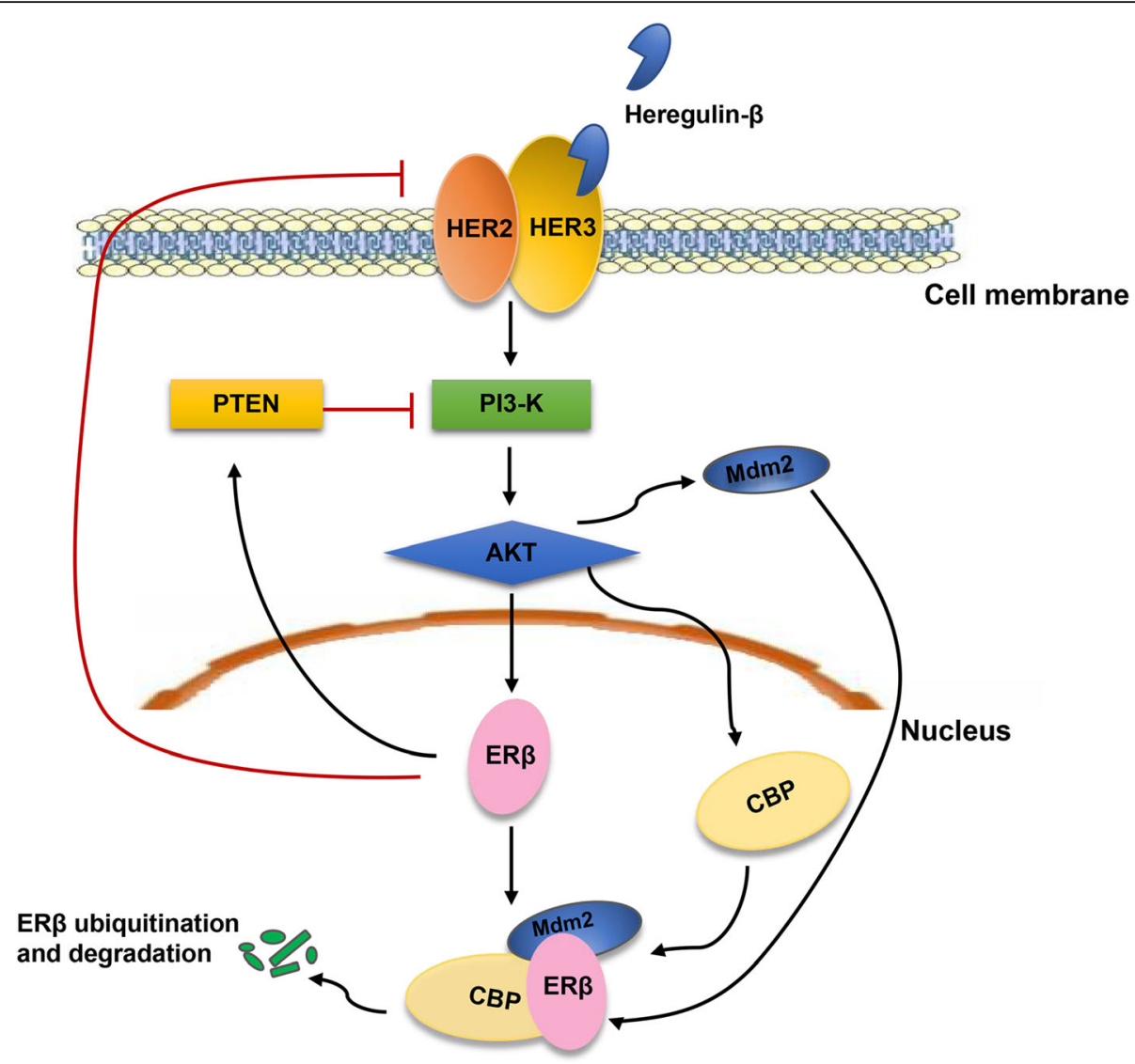

Fig. 1 The interaction between ERß and PI3-K/Akt signaling. Heregulin- $\beta$ binds to HER2/HER3 receptors, which leading to the PI3-K/Akt signaling activation. The enhancement of PI3-K/Akt signaling triggers the recruitment of the E3 ubiquitin ligase MDM2 to ER $\beta$, which is further stabilized by $C B P$, resulting in ER $\beta$ polyubiquitination. On the contrary, expression of ER $\beta$ results in a decrease in Akt signaling by increasing PTEN levels and decreasing protooncogene HER2/HER3 signaling

cells upregulates the transcription of ER $\beta 1$, which subsequently suppresses ZEB1 [88].

ER $\beta$ elicites tumor-suppressive effects, particularly with regard to suppression of metastatic phenotypes, which is characterized by the induction of a family of secreted proteins known as cystatins and the subsequent inhibition of canonical transforming growth factor (TGF- $\beta$ ) signaling [89], leading to decreased expression of a network of genes related to extracellular matrix, cell invasion and vitamin D3 metabolism [90]. There is evidence that ER $\beta$ is involved in angiogenesis in breast cancer. ER $\beta$ decreases the expression of the proangiogenic factors vascular endothelial growth factor (VEGF) and platelet-derived growth factor $\beta$ (PDGF $\beta$ ) in T47D breast cancer cells and reduces the number of intertumoral blood vessels. The expression of ER $\beta$ in cell culture results in decreased VEGF expression and PDGF $\beta$ mRNA under normoxic as well as hypoxic conditions and reduces secreted VEGF and PDGF $\beta$ protein levels in cell culture medium [91]. Furthermore, ER $\beta$ attenuates the hypoxic induction of VEGF mRNA by directly reducing hypoxia inducible factor (HIF-1 $\alpha$ ) binding to the VEGF gene promoter [92]. The inhibition of HIF- $1 \alpha$ activity by $\mathrm{ER} \beta$ expression is related to the ability of ER $\beta$ to degrade aryl hydrocarbon receptor nuclear translocator (ARNT) via ubiquitination processes, leading to the reduction of active HIF-1 $\alpha /$ ARNT complexes [93]. These results show that ER $\beta$ is capable of inhibiting HIF- $1 \alpha$-mediated transcription by downregulating ARNT, which can participate in the tumor suppressive function of $\operatorname{ER} \beta$ (Fig.2).

Other experimental studies have demonstrated that ER $\beta$ overexpression can also increase the level of integrin $\alpha \mathrm{I}$ [94], growth-inhibitory p21/WAF and epithelial cell marker cytokeratin 8 [66], consequently modulating adhesion and migration of breast cancer cells.

\section{The inhibitory effect of ER $\beta$ in cell cycle progression}

Several lines of evidence suggest that the inhibitory effect of ER $\beta$ is due to blockade of cell cycle progression. ER $\beta$ knockdown results in a significant growth of several breast cancer cells, accompanied by elevated cyclin A2 expression [66] and mitofusin 2 ( $\mathrm{mfn} 2$ ) [95]. 


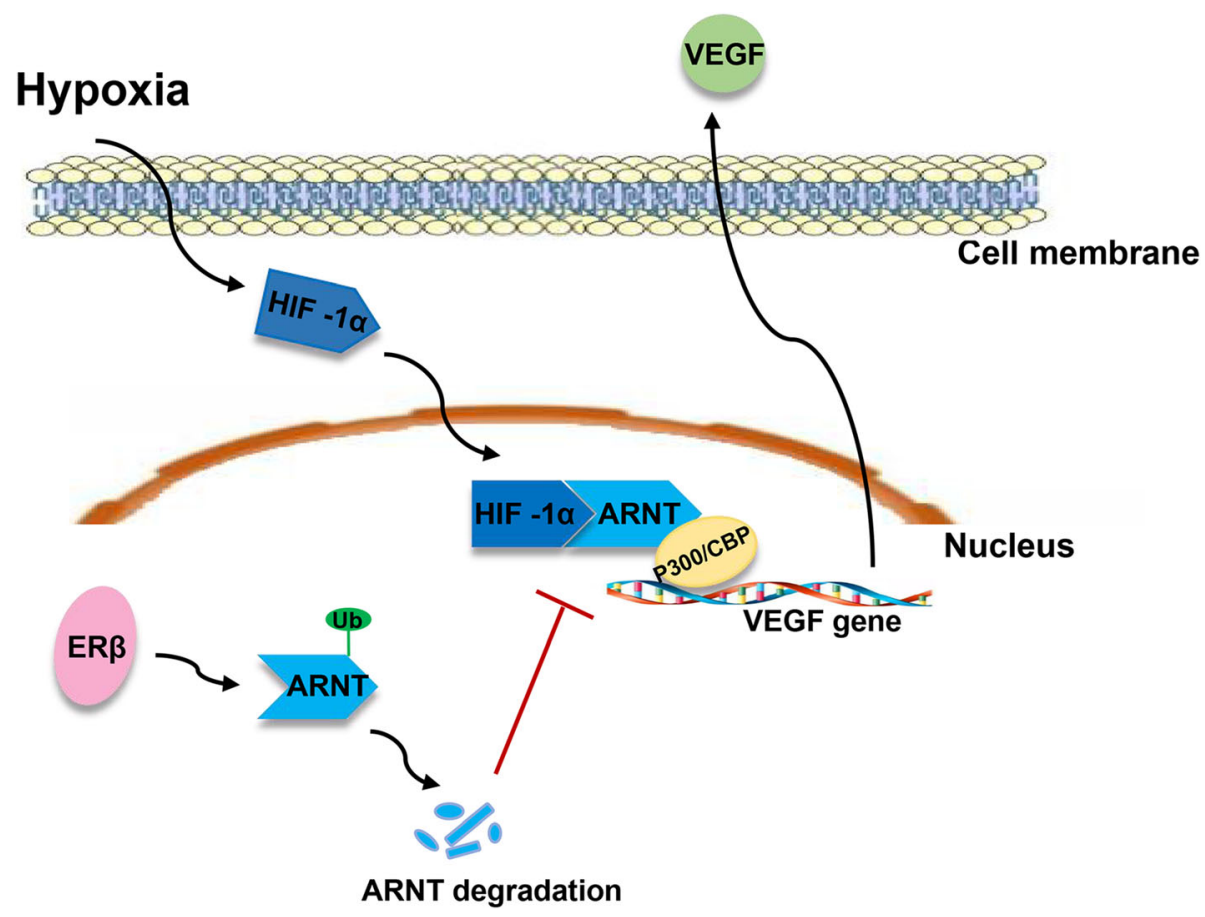

Fig. 2 ER $\beta$ reduces VEGF transcription via reducing HIF-1a/ARNT complexes. ER $\beta$ attenuated the hypoxic induction of VEGF mRNA by directly reducing HIF-1a/ARNT complexes binding to VEGF gene promoter. The inhibition of HIF-1a activity is related to the ability of ER $\beta$ to degrade ARNT via ubiquitination processes, leading to the reduction of active HIF-1a/ARNT complexes

After being treated with a combination of ER $\beta$ agonist and letrozole, tumors from mice presents an increase in ER $\beta$ levels compared to those with single drug treatment. Subsequently, decreased cyclin D1 and increased cyclin D1/CDK inhibitors p21 and p27 levels are observed, suggesting that the combination therapy may inhibit tumor growth by blocking G1/S phase cell cycle progression [96]. In TNBC, ER $\beta$ expression inhibits cell growth by inducing G1 cell cycle arrest, which was further enhanced by $17 \beta$-estradiol treatment [97].

ER $\beta$ is also involved in the G2 cell cycle [98]. Gene expression studies and ingenuity pathway analysis have identified a network of ER $\beta$-regulated genes related to cell cycle progression. ER $\beta$ causes G2 cell cycle arrest by repressing c-myc, cyclin D1, and cyclin A gene transcription and increasing the expression of p21 (Cip1) and p27 (Kip1), which leads to inhibition of proliferation [99].

Unliganded ER $\beta$ inactivates CDK1 by inhibiting cyclin $\mathrm{B} 1$ and stimulating the expression of GADD45A and BTG2, which eventually results in G2 cell cycle arrest $[100,101]$. The activation of ER $\beta$ results in decreased proliferation rates and stagnation of the cell cycle, thus inhibiting the growth of tumors.

\section{The role of ER $\beta$ in regulating mitochondrial function} ER $\beta$ can perform its role in tumor inhibition by regulating mitochondrial function and dynamics. After overexpression of ER $\beta$ in the T47D-ER $\beta$ tetracycline-inducible cell line was inhibited, a decrease in mitochondrial biogenesis is observed, together with fewer fission events [102]. The trifunctional protein beta subunit (HADHB), a mitochondrial protein that is required for $\beta$-oxidation of fatty acids, colocalized with ER $\beta$. Silencing of ER $\beta$ results in enhanced HADHB enzyme activity. This suggests that ER $\beta$ causes a significant reduction in HADHB enzyme activity and thus affects cellular oxidative stress through influencing the rate of $\beta$-oxidation of fatty acids in breast cancer cells [103].

\section{The interaction among ER $\beta$ and other proteins}

Many substances have been found to interact with ER $\beta$. Koyama et al. reported that deleted in breast cancer 1 $(D C B 1)$ can interact with ER $\beta$ by a direct interaction between the amino-terminus of $D C B 1$ and the activation function-1/2 domain of ER $\beta$, which is similar to ER $\alpha$. This interaction inhibits the transcriptional activation of $E R \beta$, as well as the transcriptional activation of ER $\beta$ on the downstream apoptosis-related gene $B C L-2$ [104].

A new ER $\beta 1$-interacting protein, inhibitor of differentiation-1 (Id1), is identified by a yeast twohybrid screening technique; this protein interacts with ER $\beta 1$ via the helix-loop-helix domain of the Id1 protein. Id 1 is the dominant negative regulator of basic helix-loop-helix (bHLH) transcription factors, which promote cell proliferation in breast cancer cells. ER $\beta$ 
binds with Id1 protein, whilst removing Id 1 inactivation of p21 expression, resulting in decreased cancer cell growth [105].

$\operatorname{ER} \beta$ is a new target of small ubiquitin-related modifier (SUMO-1). Due to further regulation by phosphorylation of additional adjacent serine residues by glycogen synthase kinase $3 \beta$ (GSK3 $\beta$ ), ER $\beta$ SUMOylation is maximized in response to hormones. SUMO-1 prevents ER $\beta$ degradation by competing with ubiquitin at the same receptor site and inhibits ER $\beta$ transcription by changing estrogen-responsive target promoter occupancy and gene expression in breast cancer cells [106].

\section{DNA methylation, microRNAs (miRNAs) and oncogenes} Evidence has confirmed that ER $\beta$ exerts its oncosuppressive role via regulation of gene transcription and RNA maturation and posttranscriptional regulation of RNA activity $[25,107,108]$, providing novel information on the biological role of ER $\beta$ in breast cancer.

\section{DNA methylation}

Many studies have confirmed that ER $\beta$ gene silencing mediated by DNA methylation is an important mechanism in breast cancer [109]. Compared to those of adjacent normal tissues, the methylation level of breast cancer is significantly higher, which may be the reason for the decreased ER $\beta$ gene expression [110]. According to Mirza et al., patients with concurrent hypermethylation of ER $\beta$ and retinoic acid receptor $\beta 2$ (RAR $\beta 2$ ) showed a significantly shorter median OS [47]. Interestingly, another study found that the methylation level of the $\mathrm{ON}$ promoter could be a more reliable parameter for prognosis in breast cancer than ER $\beta 1$ mRNA and/or protein levels [111]. Therefore, these findings may indicate the role of ERS2 methylation in breast cancer development and treatment.

\section{MicroRNAs (miRNAs) miRNAs}

miRNAs are small noncoding RNAs that participate in the regulation of gene activity and tumorigenesis [112]. Evidence has demonstrated that miRNAs are involved in regulating the expression of ER $\beta$. By targeting its 3'UTR, miR-92 downregulates ER $\beta 1$ expression. Inhibition of miR-92 in MCF-7 cells induces ER $\beta 1$ expression in a dose-dependent manner. This may be an important mechanism for the downregulation of ER $\beta$ expression in breast cancer [113]. ER $\beta$ expression also causes changes in miRNA expression. The comparison of miRNAome expression in ER $\beta$ + and ER $\beta$ - hormone-responsive breast cancer reveals 67 miRNAs with distinct different expression patterns [114]. The upregulation of some miRNAs exerts an antiproliferative effect in breast cancer [115]. Examples of miRNAs regulated by ER $\beta$ are listed in Table 2.
ER $\beta$ upregulates miR-200a/b/429 to inhibit EMT and invasion in basal-like breast cancer cells both in vitro and in vivo. The upregulation of miR-200a/b/429 leads to a decrease in downstream ZEB1 and SIP1, which triggers increased E-cadherin expression. Additionally, ER $\beta 1$ is found to be correlated with E-cadherin expression in breast cancer samples [87]. Additionally, ER $\beta$-induced downregulation of miR-10b and upregulation of miR145 [116] and miR-30a-5p [117] are found to influence the extracellular matrix (ECM) composition and significantly reduce the aggressiveness of breast cancer cells.

In $E R \beta+T N B C$, ER $\beta$ induces miR-181a-5p overexpression, which is involved in the inhibition of the cholesterol biosynthesis pathway in TNBC cells [118]. These results suggest that miRNA regulation might be a critical event in the control of the biological and clinical phenotype of breast cancer by ER $\beta$.

\section{P53}

ER $\beta$ is an activator of wild-type P53-dependent transcription and is thought to interact with P53. The upregulation of ER $\beta$ or activation with ER $\beta$ agonists results in increased nuclear P53 expression [119, 120].

The synergistic effect of ER $\beta$ and P53 inactivation functions is an important aspect of the occurrence and development of breast cancer [121]. In TNBC, P53 status, together with the ESR2 mutant, show antiproliferative effects [122]. ER $\beta 1$ upregulates target genes of mutant P53 that are associated with a normal phenotype and downregulated prometastatic factors [123]. Somatic loss of ER $\beta$ and P53 accelerates tumor development in a mouse model of mammary tumors [121]. ER $\beta$ expression leads to abrogation of S-phase and Chk1/Cdc25C-mediated $\mathrm{G}_{2} / \mathrm{M}$ checkpoints after cisplatin and doxorubicin exposure. Interestingly, this effect is found only in P53-defective breast cancer cells but not in P53 wild-type mammary cells [124].

Moreover, ER $\beta$ 's antiproliferative and proapoptosis effects in breast cancer cells involve the interaction of P53 and ER $\alpha$. ER $\beta$ reduces ER $\alpha-P 53$ binding by interacting with $P 53$, resulting in antagonization of ER $\alpha$-P53-mediated transcriptional regulation. Additionally, ER $\beta$ stimulates the accumulation of histone $\mathrm{H} 3$ lys4 trimethylation (H3K4me3) and RNA polymerase II on ER $\alpha$-repressed genes, which leads to the epigenetic activation of H3K4me3-related suppressor gene transcription, thus promoting $P 53$-based tumor suppression. ER $\beta$ also attenuates the crosstalk between ER $\alpha$ and $P 53$ by reducing corepressor NCoR and SMRT recruitment by ER $\alpha$ [125].

\section{Breast cancer 1 (BRCA1)/ breast cancer 2 (BRCA2)}

Hereditary breast cancer can account for 5 to $10 \%$ of all breast cancer patients [126], and BRCA1/BRCA2 mutations can be detected in more than $60 \%$ of hereditary breast cancer patients [127]. In BRCA1-associated hereditary breast 
Table 2 Examples of miRNAs regulated by ER $\beta$

\begin{tabular}{llll}
\hline & miRNA & Mechanism & Year (Ref.) \\
\hline Upregulated & miR-145 & inhibition of EMT & 2017 [116] \\
& miR-30a-5p & inhibition of EMT & 20117] \\
& miR-200a/b/429 $[87]$ & inhibition of EMT and invasion & $2020[118]$ \\
Downregulated & miR-181a-5p & inhibition of cholesterol biosynthesis & $2017[116]$ \\
& $m i R-10$ & regulation of ECM composition & $2013[115]$ \\
& $m i R-375$ & suppression of proliferation & \\
\hline
\end{tabular}

EMT Epithelial-mesenchymal transition, ECM Extracellular matrix

cancer, the expression of ER $\beta$ is significantly higher than that of ER $\alpha$ [128] . Therefore, the effect of estrogen in these breast cancer patients may be mainly mediated by ER $\beta$ [129]. In addition, BRCA1 mutations are common in TNBC [130], and there have been many pharmacological and nutritional studies on the relationship between BRCA1 and ER $\beta$. Studies have shown that large amounts of soy food can reduce the risk of breast cancer and improve the prognosis of breast cancer patients [131, 132] . This is mainly related to genistein, which is one of the main components of soy isoflavones and can inhibit several steps of carcinogenicity [133] . Genistein can trigger transactivation with $E R \beta$ from estrogen response element-reporter genes and is 20 - to 40 -fold more potent in stimulating ER $\beta$-mediated transcription in MCF-7 cells [134] . Besides, genistein strongly inhibits the growth of BRCA1 mutant cells, but only has a weaker effect in cells expressing wild-type BRCA1 protein. The hypersensitivity of this genistein to BRCA1 mutant cells may be related to the higher expression of ER $\beta$ [135]. The relationship between ER $\beta$ and $B R C A 1$ in breast cancer still needs further basic research to verify. As for the relationship between BRCA2 and ER $\beta$, there still a lack of research.

\section{Conclusion and outlook}

Over time, more functions and activation mechanisms mediated by ER $\beta$ have been discovered. An increasing body of evidence suggests that ER $\beta$ is thought to be a protective factor that suppresses uncontrolled proliferation, which is mediated by concentration-dependent and cell line-specific effects on cell growth and gene expression [136]. In addition, ER $\beta$ can exert its antitumor effect via gene transcription and miRNA regulation. In the clinical aspect, although the conclusions are controversial, ER $\beta$ can predict clinical outcome and response to chemotherapy or endocrine therapy. Here, we have discussed some new progress regarding the role of ER $\beta$, which merits further investigation.

Clearly, continued efforts are needed to understand the nature and function of ER $\beta$, which may offer clinical evidence when the diagnosis of breast cancer patients is ambiguous and provide a new prospect for the management of breast cancer.

\section{Abbreviations}

ER: Estrogen receptor; TAM: Tamoxifen; RFS: Recurrence-free survival; PFS: Progression-free survival; DFS: Disease-free survival; OS: Overall survival; DMFS: Distant metastases-free survival; TNBC: Triple-negative breast cancer; PR: Progesterone receptor; HER2: Human epidermal growth factor receptor-2; SERM: Selective estrogen receptor modulator; ROS: Reactive oxygen species; CBP: Binding protein; NRF-1: Nuclear respiratory factor 1; BCA2: Breast cancer associated gene 2; UCP: Uncoupling protein; SIRT3: Sirtuin 3; AKT: Protein kinase B; SAPK: Stress-activated protein kinase; PI3-K: Phosphatidylinositol-3kinase; PTEN: Phosphatase and tensin homolog deleted on chromosome ten; CREB: CAMP response element-binding; ECM: Extracellular matrix;

EGFR: Epidermal growth factor receptor; IGF-IR: Insulin-like growth factor-I receptor; JAK/STAT: Janus kinase/signal transducer and activator of transcription; EMT: Epithelial-mesenchymal transition; ZEB1: Zinc finger E-boxbinding homeobox 1; SIP1: Smad interacting protein; TGF- $\beta$ : Transforming growth factor; VEGF: Vascular endothelial growth factor; PDGF $\beta$ : Plateletderived growth factor $\beta$; HIF -1a: Hypoxia inducible factor-1a; ARNT: Aryl hydrocarbon receptor nuclear translocator; mfn2: Mitofusin2; RARß2: Retinoic acid receptor $\beta 2$; HADHB: Trifunctional protein, beta subunit; DCB1: Deleted in breast cancer 1; Id1: Inhibitor of differentiation-1; bHLH: Basic helix-loophelix; SUMO-1: Small ubiquitin-related modifier; GSK3ß: Glycogen synthase kinase 33; MicroRNAs: miRNAs; H3K4me3: Histone H3 lys4 trimethylation; BRCA1: Breast cancer 1; BRCA2: Breast cancer 2

\section{Acknowledgements}

Not applicable.

\section{Authors' contributions}

Conceptualization and Funding acquisition: Xingdang Liu. Writing - original draft: Yujing Zhou. Writing - review editing: Yujing Zhou and Xingdang Liu. The authors read and approved the final manuscript.

\section{Funding}

This work was supported by the National Natural Science Foundation of China (Grant 81571706).

Availability of data and materials Not applicable.

Ethics approval and consent to participate Not applicable.

Consent for publication

Not applicable.

\section{Competing interests}

The authors declare that they have no competing interests in this section.

Received: 12 July 2020 Accepted: 27 August 2020

Published online: 07 September 2020

\section{References}

1. Bray F, Ferlay J, Soerjomataram I, Siegel RL, Torre LA, Jemal A. Global cancer statistics 2018: GLOBOCAN estimates of incidence and mortality worldwide for 36 cancers in 185 countries. Ca-a Cancer J Clin. 2018;68(6):394-424.

2. Jensen EV. On the mechanism of estrogen action. Perspect Biol Med. 1962; 6(1):47-60. 
3. Park YR, Lee J, Jung JH, Kim WW, Park CS, Lee RK, Chae YS, Lee SJ, Park JY, Park JY, et al. Absence of estrogen receptor is associated with worse oncologic outcome in patients who were received neoadjuvant chemotherapy for breast cancer. Asian J Surg. 2020;43(3):467-75.

4. Kumar M, Salem K, Tevaarwerk AJ, Strigel RM, Fowler AM. Recent advances in imaging steroid hormone receptors in breast cancer. J Nucl Med. 2020; 61(2):172-6.

5. Kruchten MV, Glaudemans AWJM, Vries EFJD, Beets-Tan RGH, Schroder C, Dierckx R, Vries EGED, Hospers GAP. PET imaging of estrogen receptors as a diagnostic tool for breast cancer patients presenting with a clinical dilemma. J Nucl Med. 2012;53(2):182-90.

6. Kuiper G, Enmark E, PeltoHuikko M, Nilsson S, Gustafsson JA. Cloning of a novel estrogen receptor expressed in rat prostate and ovary. Proc Natl Acad Sci U S A. 1996;93(12):5925-30.

7. Bhattacharjee A, Hossain MU, Chowdhury ZM, Rahman SMA, Bhuyan ZA Salimullah M, Keya CA. Insight of druggable cannabinoids against estrogen receptor beta in breast cancer. J Biomol Struct Dyn. 2020:1-10.

8. Park H, McEachon JD, Pollock JA. Synthesis and characterization of hydrogen peroxide activated estrogen receptor beta ligands. Bioorg Med Chem. 2019;27(10):2075-82.

9. Crandall DL, Busler DE, Novak TJ, Weber RV, Kral JG. Identification of estrogen receptor beta RNA in human breast and abdominal subcutaneous adipose tissue. Biochem Biophys Res Commun. 1998;248(3):523-6.

10. Kuiper GG, Shughrue PJ, Merchenthaler I, Gustafsson JA. The estrogen receptor beta subtype: a novel mediator of estrogen action in neuroendocrine systems. Front Neuroendocrinol. 1998;19(4):253-86.

11. Balla B, Sarvari M, Kosa JP, Kocsis-Deak B, Tobias B, Arvai K, Takacs I, Podani J, Liposits Z, Lakatos P. Long-term selective estrogen receptor-beta agonist treatment modulates gene expression in bone and bone marrow of ovariectomized rats. J Steroid Biochem Mol Biol. 2019:4(188):185-94.

12. Liu JYH, Lin G, Fang MR, Rudd JA. Localization of estrogen receptor $E R$ alpha, ER beta and GPR30 on myenteric neurons of the gastrointestinal tract and their role in motility. Gen Comp Endocrinol. 2019;1(272):63-75.

13. Tamer SA, Yildirim A, Arabaci S, Ciftci S, Akin S, Sari E, Koroglu MK, Ercan F, Yuksel $\mathrm{M}$, Cevik O, et al. Treatment with estrogen receptor agonist ER beta improves torsion-induced oxidative testis injury in rats. Life Sci. 2019;1(222):203-11.

14. Le Moene O, Stavarache M, Ogawa S, Musatov S, Agmo A. Estrogen receptors alpha and beta in the central amygdala and the ventromedial nucleus of the hypothalamus: Sociosexual behaviors, fear and arousal in female rats during emotionally challenging events. Behav Brain Res. 2019; 23(367):128-42.

15. Kim H, Park J, Leem H, Cho M, Yoon JH, Maeng HJ, Lee Y. Rhododendrininduced RNF146 expression via estrogen receptor beta activation is cytoprotective against 6-OHDA-induced oxidative stress. Int J Mol Sci. 2019; 20(7):e1772

16. Sang JH, Jung SY, Wu SP, Hawkins SM, Park M, Kyo S, Jun Q, Lydon J, Tsai S, Tsai M, et al. Estrogen receptor $\beta$ modulates apoptosis complexes and the inflammasome to drive the pathogenesis of endometriosis. Cell. 2015;163(4):960-74.

17. Du M, Shan J, Feng A, Schmull S, Gu J, Song X. Oestrogen receptor beta activation protects against myocardial infarction via Notch1 signalling. Cardiovasc Drugs Ther. 2020;34(2):165-78.

18. Ofosu W, Mohamed D, Corcoran O, Ojo O. The role of oestrogen receptor beta (ER $\beta$ ) in the aetiology and treatment of type 2 diabetes mellitus. Curr Diabetes Rev. 2019;15(2):100-4.

19. Bharathi C, Anupama D, Pratibha N, Venkateshwari A. Impact of genetic variants in estrogen receptor-beta gene in the etiology of uterine leiomyomas. J Reprod Infertil. 2019;20(3):151-60.

20. Ibrahim A, Hugerth LW, Hases L, Saxena A, Seifert M, Thomas Q, Gustafsson $J$ A, Engstrand L, Williams C. Colitis-induced colorectal cancer and intestinal epithelial estrogen receptor beta impact gut microbiota diversity. Int J Cancer. 2019;144(12):3086-98.

21. Santti K, Ihalainen H, Ronty M, Karlsson C, Haglund C, Sampo M, Tarkkanen M, Blomqvist C. Estrogen receptor beta expression correlates with proliferation in desmoid tumors. J Surg Oncol. 2019;119(7):873-9.

22. Majumdar S, Rinaldi JC, Malhotra NR, Xie L, Hu DP, Gauntner TD, Grewal HS, Hu WY, Kim SH, Katzenellenbogen JA, et al. Differential actions of estrogen receptor alpha and beta via nongenomic signaling in human prostate stem and progenitor cells. Endocrinology. 2019;160(11):2692-708.

23. Liang L, Williams MD, Bell D. Expression of PTEN, androgen receptor, HER2/ neu, cytokeratin 5/6, estrogen receptor-beta, HMGA2, and PLAG1 in salivary duct carcinoma. Head Neck Pathol. 2019;13(4):529-34.
24. Litwiniuk MM, Roznowski K, Filas V, Godlewski DD, Stawicka M, Kaleta R, Breborowicz J. Expression of estrogen receptor beta in the breast carcinoma of BRCA1 mutation carriers. BMC Cancer. 2008;13(8):e100.

25. Dago DN, Scafoglio C, Rinaldi A, Memoli D, Giurato G, Nassa G, Ravo M, Rizzo F, Tarallo R, Weisz A. Estrogen receptor beta impacts hormoneinduced alternative mRNA splicing in breast cancer cells. BMC Genomics. 2015;9(16):367.

26. Ruddy SC, Lau R, Cabrita MA, McGregor C, McKay BC, Murphy LC, Wright JS, Durst T, Pratt MA. Preferential estrogen receptor beta ligands reduce $\mathrm{BCl}-2$ expression in hormone-resistant breast cancer cells to increase autophagy. Mol Cancer Ther. 2014;13(7):1882-93.

27. Kuiper G, Carlsson B, Grandien K, Enmark E, Haggblad J, Nilsson S, Gustafsson JA. Comparison of the ligand binding specificity and transcript tissue distribution of estrogen receptors alpha and beta. Endocrinology. 1997;138(3):863-70.

28. Hall JM, McDonnell DP, Korach KS. Allosteric regulation of estrogen receptor structure, function, and coactivator recruitment by different estrogen response elements. Mol Endocrinol. 2002;16(3):469-86.

29. Hawse JR, Carter JM, Aspros KGM, Bruinsma ES, Koepplin JW, Negron V, Subramaniam M, Ingle JN, Rech KL, Goetz MP. Optimized immunohistochemical detection of estrogen receptor beta using two validated monoclonal antibodies confirms its expression in normal and malignant breast tissues. Breast Cancer Res Treat. 2020;179(1):241-9.

30. Elebro K, Borgquist S, Rosendahl AH, Markkula A, Simonsson M, Jirstrom K, Rose $\mathrm{C}$, Ingvar $\mathrm{C}$, Jernstrom $\mathrm{H}$. High estrogen receptor beta expression is prognostic among adjuvant chemotherapy-treated patients-results from a population-based breast cancer cohort. Clin Cancer Res. 2017;23(3):766-77.

31. Marotti JD, Collins LC, Hu R, Tamimi RM. Estrogen receptor-beta expression in invasive breast cancer in relation to molecular phenotype: results from the Nurses' health study. Mod Pathol. 2010;23(2):197-204.

32. Girault I, Andrieu C, Tozlu S, Spyratos F, Bieche I, Lidereau R. Altered expression pattern of alternatively spliced estrogen receptor beta transcripts in breast carcinoma. Cancer Lett. 2004;215(1):101-12.

33. Tong D, Schuster $E$, Seifert M, Czerwenka K, Leodolte $S$, Zeillinger $R$. Expression of estrogen receptor beta isoforms in human breast cancer tissues and cell lines. Breast Cancer Res Treat. 2002;71(3):249-55.

34. Altundag $\mathrm{O}$, Altundag K, Gunduz M. DNA methylation inhibitor, procainamide, may decrease the tamoxifen resistance by inducing overexpression of the estrogen receptor beta in breast cancer patients. Med Hypotheses. 2004;63(4):684-7.

35. Mandusic V, Dimitrijevic B, Nikolic-Vukosavljevic D, Neskovic-Konstantinovic Z, Kanjer K, Hamann U. Different associations of estrogen receptor beta isoforms, ERbeta1 and ERbeta2, expression levels with tumor size and survival in early- and late-onset breast cancer. Cancer Lett. 2012;321(1):73-9.

36. Abbasi S. Estrogen receptor-beta gene polymorphism in women with breast cancer at the imam Khomeini hospital complex, Iran. BMC Med Genet. 2010;7(11):e109.

37. Yu KD, Rao NY, Chen AX, Fan L, Yang C, Shao ZM. A systematic review of the relationship between polymorphic sites in the estrogen receptor-beta (ESR2) gene and breast cancer risk. Breast Cancer Res Treat. 2011;126(1):37-45.

38. Xia W, Wang T, Sun D, Mao W, Xie X. Association of estrogen receptor-beta (ESR2) polymorphism and cancer risk: a meta-analysis. Eur J Gynaecol Oncol. 2016;37(4):530-8.

39. Chen L, Liang Y, Qiu J, Zhang L, Chen X, Luo X, Jiang J. Significance of rs1271572 in the estrogen receptor beta gene promoter and its correlation with breast cancer in a southwestern Chinese population. J Biomed Sci. 2013;20:32.

40. Murphy $L C$, Leygue $E$. The role of estrogen receptor-beta in breast cancer. Semin Reprod Med. 2012;30(1):5-13.

41. Hopp TA, Weiss HL, Parra IS, Cui Y, Osborne CK, Fuqua SA. Low levels of estrogen receptor beta protein predict resistance to tamoxifen therapy in breast cancer. Clin Cancer Res. 2004;10(22):7490-9.

42. de Cremoux P, Tran-Perennou C, Elie C, Boudou E, Barbaroux C, Poupon MF, De Rycke $Y$, Asselain B, Magdelenat H. Quantitation of estradiol receptors alpha and beta and progesterone receptors in human breast tumors by real-time reverse transcription-polymerase chain reaction. Correlation with protein assays. Biochem Pharmacol. 2002;64(3):507-15.

43. Stefanou D, Batistatou A, Briasoulis E, Arkoumani E, Agnantis NJ. Estrogen receptor beta (ERbeta) expression in breast carcinomas is not correlated with estrogen receptor alpha (ERalpha) and prognosis: the Greek experience. Eur J Gynaecol Oncol. 2004;25(4):457-61. 
44. Chang J, Liu J, Li H, Li J, Mu Y, Feng B. Expression of ERbeta gene in breast carcinoma and the relevance in neoadjuvant therapy. Oncol Lett. 2017;13(3): 1641-6.

45. Madeira M, Mattar A, Logullo AF, Soares FA, Gebrim LH. Estrogen receptor alpha/beta ratio and estrogen receptor beta as predictors of endocrine therapy responsiveness-a randomized neoadjuvant trial comparison between anastrozole and tamoxifen for the treatment of postmenopausal breast cancer. BMC Cancer. 2013;18(13):425.

46. Oueslati M, Bittaieb I, Sassi N, Jemaa AB, Gamoudi A, Rahal K, Oueslati R. ERalpha and ERbeta co-expression: an indicator of aggressive tumors and hormonal sensitivity. Oncol Lett. 2017;14(2):1675-82.

47. Mirza S, Sharma G, Parshad R, Srivastava A, Gupta SD, Ralhan R. Clinical significance of promoter hypermethylation of ERbeta and RARbeta2 in tumor and serum DNA in Indian breast cancer patients. Ann Surg Oncol. 2012;19(9):3107-15.

48. Guo L, Zhang Y, Zhang W, Yilamu D. Correlation between estrogen receptor beta expression and the curative effect of endocrine therapy in breast cancer patients. Exp Ther Med. 2014;7(6):1568-72.

49. Guo L, Zhang YU, Yilamu D, Liu S, Guo C. ERbeta overexpression results in endocrine therapy resistance and poor prognosis in postmenopausal ERalpha-positive breast cancer patients. Oncol Lett. 2016;11(2):1531-6.

50. Yan M, Rayoo M, Takano EA, Fox SB. Nuclear and cytoplasmic expressions of ERbeta1 and ERbeta2 are predictive of response to therapy and alters prognosis in familial breast cancers. Breast Cancer Res Treat. 2011;126(2): 395-405.

51. Austin D, Hamilton N, Elshimali Y, Pietras R, Wu Y, Vadgama J. Estrogen receptor-beta is a potential target for triple negative breast cancer treatment. Oncotarget. 2018;9(74):33912-30

52. Wisinski KB, Xu W, Tevaarwerk AJ, Saha S, Kim K, Traynor A, Dietrich L, Hegeman R, Patel D, Blank J, et al. Targeting estrogen receptor beta in a phase 2 study of high-dose estradiol in metastatic triple-negative breast cancer: a Wisconsin oncology network study. Clin Breast Cancer. 2016;16(4): 256-61

53. Shanle EK, Onitilo AA, Huang W, Kim K, Zang C, Engel JM, Xu W, Wisinski KB. Prognostic significance of full-length estrogen receptor beta expression in stage I-III triple negative breast cancer. Am J Transl Res. 2015;7(7):1246-59.

54. Guo L, Zhu Q, Aisimutuola M, Yilamu D, Liu S, Jakulin A. Expression and prognostic value of estrogen receptor beta in patients with triple-negative and triple-positive breast cancer. Exp Ther Med. 2015;9(6):2147-50.

55. Hamilton N, Marquez-Garban D, Mah V, Fernando G, Elshimali Y, Garban H, Elashoff D, Vadgama J, Goodglick L, Pietras R. Biologic roles of estrogen receptor-beta and insulin-like growth factor-2 in triple-negative breast cancer. Biomed Res Int. 2015;2015:e925703.

56. Wang J, Zhang C, Chen K, Tang H, Tang J, Song C, Xie X. ERbeta1 inversely correlates with PTEN/PI3K/AKT pathway and predicts a favorable prognosis in triple-negative breast cancer. Breast Cancer Res Treat. 2015;152(2):255-69.

57. Motomura K, Ishitobi $M$, Komoike $Y$, Koyama $H$, Nagase $H$, Inaji $H$, Noguchi S. Expression of estrogen receptor beta and phosphorylation of estrogen receptor alpha serine 167 correlate with progression-free survival in patients with metastatic breast cancer treated with aromatase inhibitors. Oncology. 2010;79(1-2):55-61.

58. Hamilton-Burke W, Coleman L, Cummings M, Green CA, Holliday DL, Horgan K, Maraqa L, Peter MB, Pollock S, Shaaban AM, et al. Phosphorylation of estrogen receptor beta at serine 105 is associated with good prognosis in breast cancer. Am J Pathol. 2010;177(3):1079-86.

59. Lam HM, Suresh Babu CV, Wang J, Yuan Y, Lam YW, Ho SM, Leung YK. Phosphorylation of human estrogen receptor-beta at serine 105 inhibits breast cancer cell migration and invasion. Mol Cell Endocrinol. 2012;358(1):27-35.

60. Speirs V, Malone C, Walton DS, Kerin MJ, Atkin SL. Increased expression of estrogen receptor beta mRNA in tamoxifen-resistant breast cancer patients. Cancer Res. 1999;59(21):5421-4

61. Pons DG, Torrens-Mas M, Nadal-Serrano M, Sastre-Serra J, Roca P, Oliver J. The presence of estrogen receptor beta modulates the response of breast cancer cells to therapeutic agents. Int J Biochem Cell Biol. 2015;66:85-94.

62. Wu X, Subramaniam M, Grygo SB, Sun Z, Negron V, Lingle WL, Goetz MP, Ingle JN, Spelsberg TC, Hawse JR. Estrogen receptor-beta sensitizes breast cancer cells to the anti-estrogenic actions of endoxifen. Breast Cancer Res. 2011;13(2):R27.

63. Razandi M, Pedram A, Jordan VC, Fuqua S, Levin ER. Tamoxifen regulates cell fate through mitochondrial estrogen receptor beta in breast cancer. Oncogene. 2013;32(27):3274-85.
64. Ivanova MM, Luken KH, Zimmer AS, Lenzo FL, Smith RJ, Arteel MW, Kollenberg TJ, Mattingly KA, Klinge CM. Tamoxifen increases nuclea respiratory factor 1 transcription by activating estrogen receptor beta and AP-1 recruitment to adjacent promoter binding sites. FASEB J. 2011;25(4): 1402-16.

65. Lindberg K, Helguero LA, Omoto Y, Gustafsson JA, Haldosen LA. Estrogen receptor beta represses Akt signaling in breast cancer cells via downregulation of HER2/HER3 and upregulation of PTEN: implications for tamoxifen sensitivity. Breast Cancer Res. 2011;13(2):R43.

66. Treeck O, Lattrich C, Springwald A, Ortmann O. Estrogen receptor beta exerts growth-inhibitory effects on human mammary epithelial cells. Breast Cancer Res Treat. 2010;120(3):557-65.

67. Niu XL, Wang Y, Yao Z, Duan H, Li Z, Liu W, Zhang H, Deng WM. Autocrine interferon-gamma may affect malignant behavior and sensitivity to tamoxifen of MCF-7 via estrogen receptor beta subtype. Oncol Rep. 2015; 34(6):3120-30

68. Pitta CA, Papageorgis P, Charalambous C, Constantinou Al. Reversal of ERbeta silencing by chromatin modifying agents overrides acquired tamoxifen resistance. Cancer Lett. 2013;337(2):167-76.

69. Jiang H, Fan J, Cheng L, Hu P, Liu R. The anticancer activity of genistein is increased in estrogen receptor beta 1-positive breast cancer cells. Onco Targets Ther. 2018;11:8153-63.

70. Lee MT, Ho SM, Tarapore P, Chung I, Leung YK. Estrogen receptor beta isoform 5 confers sensitivity of breast cancer cell lines to chemotherapeutic agent-induced apoptosis through interaction with Bcl2L12. Neoplasia. 2013; 15(11):1262-71.

71. Zheng N, Liu L, Liu W, Zhang P, Huang H, Zang L, Hayashi T, Tashiro S, Onodera S, Xia M, et al. ERbeta up-regulation was involved in silibinininduced growth inhibition of human breast cancer MCF-7 cells. Arch Biochem Biophys. 2016;1(591):141-9.

72. Greish K, Nehoff H, Bahman F, Pritchard T, Taurin S. Raloxifene nano-micelles effect on triple-negative breast cancer is mediated through estrogen receptor-beta and epidermal growth factor receptor. J Drug Target. 2019; 27(8):903-16.

73. Tu Z, Li H, Ma Y, Tang B, Tian J, Akers W, Achilefu S, Gu Y. The enhanced antiproliferative response to combined treatment of trichostatin a with raloxifene in MCF-7 breast cancer cells and its relevance to estrogen receptor beta expression. Mol Cell Biochem. 2012;366(1-2):111-22.

74. Anestis A, Sarantis P, Theocharis S, Zoi I, Tryfonopoulos D, Korogiannos A, Koumarianou A, Xingi E, Thomaidou D, Kontos M, et al. Estrogen receptor beta increases sensitivity to enzalutamide in androgen receptor-positive triple-negative breast cancer. J Cancer Res Clin Oncol. 2019;145(5):1221-33.

75. Dall GV, Hawthorne S, Seyed-Razavi Y, Vieusseux J, Wu W, Gustafsson JA, Byrne D, Murphy L, Risbridger GP, Britt KL. Estrogen receptor subtypes dictate the proliferative nature of the mammary gland. J Endocrinol. 2018; 237(3):323-36.

76. Chang EC, Frasor J, Komm B, Katzenellenbogen BS. Impact of estrogen receptor beta on gene networks regulated by estrogen receptor alpha in breast cancer cells. Endocrinology. 2006;147(10):4831-42.

77. Bartella V, Rizza P, Barone I, Zito D, Giordano F, Giordano C, Catalano S, Mauro L, Sisci D, Panno ML, et al. Estrogen receptor beta binds Sp1 and recruits a corepressor complex to the estrogen receptor alpha gene promoter. Breast Cancer Res Treat. 2012;134(2):569-81.

78. Lee $Y H$, Sun $Y$, Gerweck LE, Glickman RD. Regulation of DNA damage response by estrogen receptor beta-mediated inhibition of breast cancer associated gene 2. Biomedicines. 2015;3(2):182-200.

79. Sastre-Serra J, Nadal-Serrano M, Pons DG, Valle A, Garau I, Garcia-Bonafe M, Oliver J, Roca P. The oxidative stress in breast tumors of postmenopausal women is ERalpha/ERbeta ratio dependent. Free Radic Biol Med. 2013;8(61): $11-7$.

80. Bussink J, van der Kogel AJ, Kaanders J. Activation of the PI3-K/AKT pathway and implications for radioresistance mechanisms in head and neck cancer. Lancet Oncol. 2008;9(3):288-96.

81. Treeck O, Schuler-Toprak S, Skrzypczak M, Weber F, Ortmann O. Knockdown of PTEN decreases expression of estrogen receptor beta and tamoxifen sensitivity of human breast cancer cells. Steroids. 2020;153:e108521.

82. Sanchez M, Picard N, Sauve K, Tremblay A. Coordinate regulation of estrogen receptor beta degradation by $\mathrm{Mdm} 2$ and CREB-binding protein in response to growth signals. Oncogene. 2013;32(1):117-26.

83. Zhao L, Huang S, Mei S, Yang Z, Xu L, Zhou N, Yang Q, Shen Q, Wang W, Le $X$, et al. Pharmacological activation of estrogen receptor beta augments 
innate immunity to suppress cancer metastasis. Proc Natl Acad Sci U S A. 2018;115(16):E3673-e81.

84. Hinsche O, Girgert R, Emons G, Grundker C. Estrogen receptor beta selective agonists reduce invasiveness of triple-negative breast cancer cells. Int J Oncol. 2015;46(2):878-84.

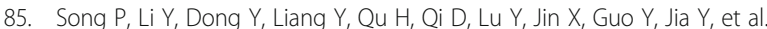
Estrogen receptor $\beta$ inhibits breast cancer cells migration and invasion through CLDN6-mediated autophagy. J Exp Clin Cancer Res. 2019;38(1):354.

86. Piperigkou Z, Bouris P, Onisto M, Franchi M, Kletsas D, Theocharis AD, Karamanos NK. Estrogen receptor beta modulates breast cancer cells functional properties, signaling and expression of matrix molecules. Matrix Biol. 2016;12(56):4-23.

87. Thomas C, Rajapaksa G, Nikolos F, Hao R, Katchy A, McCollum CW Bondesson M, Quinlan P, Thompson A, Krishnamurthy S, et al. ERbeta1 represses basal breast cancer epithelial to mesenchymal transition by destabilizing EGFR. Breast Cancer Res. 2012;14(6):R148.

88. Song W, Tang $L, X u Y$, Sun Q, Yang F, Guan X. ERbeta1 inhibits metastasis of androgen receptor-positive triple-negative breast cancer by suppressing ZEB1. J Exp Clin Cancer Res. 2017;36(1):75.

89. Reese JM, Bruinsma ES, Nelson AW, Chernukhin I, Carroll JS, Li Y, Subramaniam M, Suman VJ, Negron V, Monroe DG, et al. ERbeta-mediated induction of cystatins results in suppression of TGFbeta signaling and inhibition of triple-negative breast cancer metastasis. Proc Natl Acad Sci U S A. 2018;115(41):E9580-e9.

90. Schuler-Toprak S, Haring J, Inwald EC, Moehle C, Ortmann O, Treeck O. Agonists and knockdown of estrogen receptor beta differentially affect invasion of triplenegative breast cancer cells in vitro. BMC Cancer. 2016;16(1):951.

91. Hartman J, Lindberg K, Morani A, Inzunza J, Strom A, Gustafsson JA. Estrogen receptor beta inhibits angiogenesis and growth of T47D breast cancer xenografts. Cancer Res. 2006;66(23):11207-13.

92. Lim W, Park Y, Cho J, Park C, Park J, Park YK, Park H, Lee Y. Estrogen receptor beta inhibits transcriptional activity of hypoxia inducible factor-1 through the downregulation of arylhydrocarbon receptor nuclear translocator. Breast Cancer Res. 2011;13(2):R32.

93. Park C, Lee Y. Overexpression of ERbeta is sufficient to inhibit hypoxiainducible factor-1 transactivation. Biochem Biophys Res Commun. 2014; 450(1):261-6.

94. Lindberg K, Strom A, Lock JG, Gustafsson JA, Haldosen LA, Helguero LA. Expression of estrogen receptor beta increases integrin alpha1 and integrin beta1 levels and enhances adhesion of breast cancer cells. J Cell Physiol. 2010;222(1):156-67.

95. Ma L, Liu Y, Geng C, Qi X, Jiang J. Estrogen receptor beta inhibits estradiolinduced proliferation and migration of MCF-7 cells through regulation of mitofusin 2. Int J Oncol. 2013;42(6):1993-2000.

96. Nair HB, Kirma NB, Ganapathy M, Vadlamudi RK, Tekmal RR. Estrogen receptorbeta activation in combination with letrozole blocks the growth of breast cancer tumors resistant to letrozole therapy. Steroids. 2011;76(8):792-6.

97. Shanle EK, Zhao Z, Hawse J, Wisinski K, Keles S, Yuan M, Xu W. Research resource: global identification of estrogen receptor beta target genes in triple negative breast cancer cells. Mol Endocrinol. 2013;27(10):1762-75.

98. Hodges-Gallagher L, Valentine CD, El Bader S, Kushner PJ. Estrogen receptor beta increases the efficacy of antiestrogens by effects on apoptosis and cell cycling in breast cancer cells. Breast Cancer Res Treat. 2008;109(2):241-50.

99. Paruthiyil S, Parmar H, Kerekatte V, Cunha GR, Firestone GL, Leitman DC. Estrogen receptor beta inhibits human breast cancer cell proliferation and tumor formation by causing a G2 cell cycle arrest. Cancer Res. 2004;64(1): 423-8.

100. Reese JM, Bruinsma ES, Monroe DG, Negron V, Suman VJ, Ingle JN, Goetz MP, Hawse JR. ERbeta inhibits cyclin dependent kinases 1 and 7 in triple negative breast cancer. Oncotarget. 2017;8(57):96506-21.

101. Paruthiyil S, Cvoro A, Tagliaferri M, Cohen I, Shtivelman E, Leitman DC. Estrogen receptor beta causes a G2 cell cycle arrest by inhibiting CDK1 activity through the regulation of cyclin B1, GADD45A, and BTG2. Breast Cancer Res Treat. 2011;129(3):777-84.

102. Sastre-Serra J, Nadal-Serrano M, Pons DG, Roca P, Oliver J. The overexpression of ERbeta modifies estradiol effects on mitochondrial dynamics in breast cancer cell line. Int J Biochem Cell Biol. 2013;45(7):1509-15.

103. Zhou Z, Zhou J, Du Y. Estrogen receptor beta interacts and colocalizes with HADHB in mitochondria. Biochem Biophys Res Commun. 2012;427(2):305-8.

104. Koyama S, Wada-Hiraike O, Nakagawa S, Tanikawa M, Hiraike H, Miyamoto Y, Sone K, Oda K, Fukuhara H, Nakagawa K, et al. Repression of estrogen receptor beta function by putative tumor suppressor DBC1. Biochem Biophys Res Commun. 2010;392(3):357-62.

105. Chen L, Qiu J, Yang C, Yang X, Chen X, Jiang J, Luo X. Identification of a novel estrogen receptor beta1 binding partner, inhibitor of differentiation-1, and role of ERbeta1 in human breast cancer cells. Cancer Lett. 2009;278(2): 210-9.

106. Picard N, Caron V, Bilodeau S, Sanchez M, Mascle X, Aubry M, Tremblay A. Identification of estrogen receptor beta as a SUMO-1 target reveals a novel phosphorylated sumoylation motif and regulation by glycogen synthase kinase 3beta. Mol Cell Biol. 2012;32(14):2709-21.

107. Tarallo R, Giurato G, Bruno G, Ravo M, Rizzo F, Salvati A, Ricciardi L, Marchese G, Cordella A, Rocco T, et al. The nuclear receptor ERbeta engages AGO2 in regulation of gene transcription, RNA splicing and RISC loading. Genome Biol. 2017;18(1):189.

108. Alexandrova E, Giurato G, Saggese P, Pecoraro G, Lamberti J, Ravo M, Rizzo F, Rocco D, Tarallo R, Nyman TA, et al. Interaction proteomics identifies ERbeta association with chromatin repressive complexes to inhibit cholesterol biosynthesis and exert an oncosuppressive role in triplenegative breast cancer. Mol Cell Proteomics. 2020;19(2):245-60.

109. Zhao C, Lam EW, Sunters A, Enmark E, De Bella MT, Coombes RC, Gustafsson JA, Dahlman-Wright K. Expression of estrogen receptor beta isoforms in normal breast epithelial cells and breast cancer: regulation by methylation. Oncogene. 2003;22(48):7600-6.

110. Gao L, Qi X, Hu K, Zhu R, Xu W, Sun S, Zhang L, Yang X, Hua B, Liu G. Estrogen receptor beta promoter methylation: a potential indicator of malignant changes in breast cancer. Arch Med Sci. 2016;12(1):129-36.

111. Bozovic A, Markicevic M, Dimitrijevic B, Jovanovic Cupic S, Krajnovic M, Lukic $\mathrm{S}$, Mandusic V. Potential clinical significance of ERbeta ON promoter methylation in sporadic breast cancer. Med Oncol. 2013;30(3):642.

112. Calin GA, Croce CM. MicroRNA signatures in human cancers. Nat Rev Cancer. 2006;6(11):857-66.

113. Al-Nakhle H, Burns PA, Cummings M, Hanby AM, Hughes TA, Satheesha S, Shaaban AM, Smith L, Speirs V. Estrogen receptor beta1 expression is regulated by miR-92 in breast cancer. Cancer Res. 2010;70(11):4778-84.

114. Paris O, Ferraro L, Grober OM, Ravo M, De Filippo MR, Giurato G, Nassa G, Tarallo R, Cantarella C, Rizzo F, et al. Direct regulation of microRNA biogenesis and expression by estrogen receptor beta in hormoneresponsive breast cancer. Oncogene. 2012;31(38):4196-206.

115. Chen J, Zhao X, Ye Y, Wang Y, Tian J. Estrogen receptor beta-mediated proliferative inhibition and apoptosis in human breast cancer by calycosin and formononetin. Cell Physiol Biochem. 2013;32(6):1790-7.

116. Piperigkou Z, Franchi M, Gotte M, Karamanos NK. Estrogen receptor beta as epigenetic mediator of miR-10b and miR-145 in mammary cancer. Matrix Biol. 2017;12(64):94-111.

117. Nassa G, Tarallo R, Giurato G, De Filippo MR, Ravo M, Rizzo F, Stellato C, Ambrosino C, Baumann M, Lietzen N, et al. Post-transcriptional regulation of human breast cancer cell proteome by unliganded estrogen receptor beta via microRNAs. Mol Cell Proteomics. 2014;13(4):1076-90.

118. Alexandrova E, Lamberti J, Saggese P, Pecoraro G, Memoli D, Cappa VM, Ravo M, lorio R, Tarallo R, Rizzo F, et al. Small non-coding RNA profiling identifies miR-181a-5p as a mediator of estrogen receptor beta-induced inhibition of cholesterol biosynthesis in triple-negative breast cancer. Cells. 2020;9(4):874.

119. Cotrim CZ, Fabris V, Doria ML, Lindberg K, Gustafsson JA, Amado F, Lanari C, Helguero LA. Estrogen receptor beta growth-inhibitory effects are repressed through activation of MAPK and PI3K signalling in mammary epithelial and breast cancer cells. Oncogene. 2013;32(19):2390-402.

120. Bado I, Pham E, Soibam B, Nikolos F, Gustafsson JA, Thomas C. ERbeta alters the chemosensitivity of luminal breast cancer cells by regulating p53 function. Oncotarget. 2018;9(32):22509-22.

121. Bado I, Nikolos F, Rajapaksa G, Wu W, Castaneda J, Krishnamurthy S, Webb P, Gustafsson JA, Thomas C. Somatic loss of estrogen receptor beta and p53 synergize to induce breast tumorigenesis. Breast Cancer Res. 2017;19(1):79.

122. Mukhopadhyay UK, Oturkar CC, Adams C, Wickramasekera N, Bansal S, Medisetty R, Miller A, Swetzig WM, Silwal-Pandit L, Borresen-Dale AL, et al. TP53 status as a determinant of pro- vs anti-tumorigenic effects of estrogen receptor-beta in breast cancer. J Natl Cancer Inst. 2019;111(11):1202-15.

123. Bado I, Nikolos F, Rajapaksa G, Gustafsson JA, Thomas C. ERbeta decreases the invasiveness of triple-negative breast cancer cells by regulating mutant p53 oncogenic function. Oncotarget. 2016;7(12):13599-611.

124. Thomas CG, Strom A, Lindberg K, Gustafsson JA. Estrogen receptor beta decreases survival of p53-defective cancer cells after DNA damage by 
impairing G(2)/M checkpoint signaling. Breast Cancer Res Treat. 2011;127(2): $417-27$.

125. Lu W, Katzenellenbogen BS. Estrogen receptor-beta modulation of the ERalpha-p53 loop regulating gene expression, proliferation, and apoptosis in breast cancer. Horm Cancer. 2017;8(4):230-42.

126. Mahdavi M, Nassiri M, Kooshyar MM, Vakili-Azghandi M, Avan A, Sandry R, Pillai S, Lam AKY, Gopalan V. Hereditary breast cancer; genetic penetrance and current status with BRCA. J Cell Physiol. 2019;234(5):5741-50.

127. Hawsawi YM, Al-Numair NS, Sobahy TM, Al-Ajmi AM, Al-Harbi RM, Baghdadi MA, Oyouni AA, Alamer OM. The role of BRCA1/2 in hereditary and familial breast and ovarian cancers. Mol Genet Genom Med. 2019;7(9):7.

128. Litwiniuk MM, Roznowski K, Filas V, Godlewski DD, Stawicka M, Kaleta R, Breborowicz $\mathrm{J}$. Expression of estrogen receptor beta in the breast carcinoma of BRCA1 mutation carriers. BMC Cancer. 2008;8:8.

129. Chen JQ, Russo J. ERa-negative and triple negative breast cancer: molecular features and potential therapeutic approaches. Biochim Biophys Acta. 2009; 1796(2):162-75.

130. Qi F, Qin WX, Zang YS. Molecular mechanism of triple-negative breast cancer-associated BRCA1 and the identification of signaling pathways. Oncol Lett. 2019;17(3):2905-14

131. Li Y, Li S, Meng X, Gan RY, Zhang JJ, Li HB. Dietary natural products for prevention and treatment of breast Cancer. Nutrients. 2017:9(7):38.

132. Shu XO, Zheng Y, Cai H, Gu K, Chen Z, Zheng W, Lu W. Soy food intake and breast Cancer survival. Jama-J Am Med Assoc. 2009:302(22):2437-43.

133. Douglas CC, Johnson SA, Arjmandi BH. Soy and its Isoflavones: the truth behind the science in breast Cancer. Anticancer Agents Med Chem. 2013; 13(8):1178-87.

134. Chrzan BG, Bradford PG. Phytoestrogens activate estrogen receptor betal and estrogenic responses in human breast and bone cancer cell lines. Mol Nutr Food Res. 2010;51(2):171-7.

135. Privat M, Aubel C, Arnould S, Communal Y, Ferrara M, Bignon YJ. Breast cancer cell response to genistein is conditioned by BRCA1 mutations. Biochem Biophys Res Commun. 2009;379(3):785-9.

136. Lattrich C, Stegerer A, Haring J, Schuler S, Ortmann O, Treeck O. Estrogen receptor beta agonists affect growth and gene expression of human breast cancer cell lines. Steroids. 2013;78(2):195-202.

\section{Publisher's Note}

Springer Nature remains neutral with regard to jurisdictional claims in published maps and institutional affiliations.

Ready to submit your research? Choose BMC and benefit from:

- fast, convenient online submission

- thorough peer review by experienced researchers in your field

- rapid publication on acceptance

- support for research data, including large and complex data types

- gold Open Access which fosters wider collaboration and increased citations

- maximum visibility for your research: over $100 \mathrm{M}$ website views per year

At $\mathrm{BMC}$, research is always in progress.

Learn more biomedcentral.com/submissions 